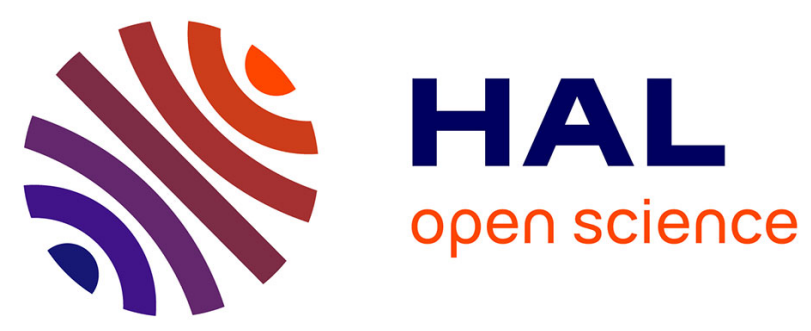

\title{
A bridged low band gap A-D-A quaterthiophene as efficient donor for organic solar cells
}

Francois Baert, Clement Cabanetos, Antoine Leliege, Eva Kirchner, Olivier Segut, Olivier Aleveque, Magali Allain, Gijun Seo, Sungyeop Jung, Denis Tondelier, et al.

\section{To cite this version:}

Francois Baert, Clement Cabanetos, Antoine Leliege, Eva Kirchner, Olivier Segut, et al.. A bridged low band gap A-D-A quaterthiophene as efficient donor for organic solar cells. Journal of Materials Chemistry C, 2015, 3, pp.390-398. 10.1039/c4tc02212b . hal-01156570

\author{
HAL Id: hal-01156570 \\ https://hal.science/hal-01156570
}

Submitted on 17 Nov 2015

HAL is a multi-disciplinary open access archive for the deposit and dissemination of scientific research documents, whether they are published or not. The documents may come from teaching and research institutions in France or abroad, or from public or private research centers.
L'archive ouverte pluridisciplinaire HAL, est destinée au dépôt et à la diffusion de documents scientifiques de niveau recherche, publiés ou non, émanant des établissements d'enseignement et de recherche français ou étrangers, des laboratoires publics ou privés. 


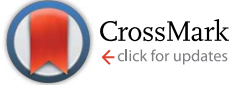

Cite this: J. Mater. Chem. C, 2015, 3 , 390

Received 1st October 2014

Accepted 7th November 2014

DOI: $10.1039 / \mathrm{c} 4 \mathrm{tc} 02212 \mathrm{~b}$

www.rsc.org/MaterialsC

\section{A bridged low band gap A-D-A quaterthiophene as efficient donor for organic solar cells $\uparrow$}

François Baert, ${ }^{a}$ Clément Cabanetos, ${ }^{a}$ Antoine Leliège, ${ }^{a}$ Eva Kirchner, ${ }^{a}$ Olivier Segut, ${ }^{a}$ Olivier Alévêque, ${ }^{a}$ Magali Allain, ${ }^{a}$ Gijun Seo, ${ }^{b}$ Sungyeop Jung, ${ }^{\text {b }}$ Denis Tondelier, ${ }^{\mathrm{b}}$ Bernard Geffroy, ${ }^{c}$ Jean Roncali, ${ }^{a}$ Philippe Leriche ${ }^{a}$ and Philippe Blanchard ${ }^{\star a}$

$\alpha, \omega$-Bis(dicyanovinyl)quaterthiophene 1 with a median 4,4-diethyl-4H-cyclopenta[2,1-b:3,4- $\left.b^{\prime}\right]$ dithiophene has been synthesized. UV-Vis absorption data show that the covalent bridging of the inner 2,2'-bithiophene leads to a significant reduction of the HOMO-LUMO gap essentially due to an increase of the HOMO level as confirmed by electrochemical and theoretical results. X-ray diffraction analysis of a single crystal of 1 shows that except for the out-of-plane ethyl groups, the conjugated system displays a quasi-planar geometry while the molecular packing exhibits strong $\pi$-stacking interactions and multiple short intermolecular contacts. Quaterthiophene 1 has been used as active donor material in organic solar cells of various architectures including bi-layer planar hetero-junctions and hybrid coevaporated bulk hetero-junctions with $\mathrm{C}_{60}$ as electron acceptor material. A maximum conversion efficiency of $4.30 \%$ is obtained with a hybrid co-evaporated device. These results are discussed in terms of structure-properties relationships with reference to the open-chain parent $\alpha, \omega$-bis(dicyanovinyl) quaterthiophene 2 .

\section{Introduction}

Small $\pi$-conjugated molecules containing electron-donating and electron-accepting units are a focus of considerable current interest as active donor materials in organic photovoltaics $(\mathrm{OPV}){ }^{1}$ Although solution-processed OPV cells based on low band gap conjugated polymers have reached power conversion efficiencies (PCE) in the range of $9.0 \%$ for single junction devices, ${ }^{2}$ discrete molecules present some advantages in terms of reproducibility of synthesis and purification and analysis of structure-properties relationships. ${ }^{1,3}$ While initial prototypes of solution-processed molecular bulk hetero-junction (BHJ) exhibited modest performance, ${ }^{4}$ the field has rapidly progressed and recently, several groups have reported PCE in the 7.0-8.0\% range by combining molecular donors of sophisticated design with $\mathrm{PC}_{71} \mathrm{BM}$ as acceptor and specific additives. ${ }^{5-7}$ In parallel, OPV cells based on vacuum-deposited molecular donors have also recorded considerable progress and PCE of $6.0-7.0 \%$ have been reported for multi-layer planar hetero-junction (PHJ) cells combining molecular donors and $\mathrm{C}_{60}$ or $\mathrm{C}_{70}$ as acceptor. ${ }^{8-10} \mathrm{An}$

${ }^{a}$ MOLTECH-Anjou, CNRS UMR 6200, University of Angers, Group Linear Conjugated Systems, 2 Bd Lavoisier, 49045 Angers, France. E-mail: philippe.blanchard@ univ-angers.fr

${ }^{b}$ LPICM, Ecole Polytechnique, CNRS UMR-7647, 91128 Palaiseau, France

'LICSEN, CEA Saclay IRAMIS/NIMBE, 91191 Gif sur Yvette, France

$\dagger$ Electronic supplementary information (ESI) available. CCDC 1007813. For ESI and crystallographic data in CIF or other electronic format see DOI: $10.1039 / \mathrm{c} 4 \mathrm{tc} 02212 \mathrm{~b}$ interesting advantage of vacuum-deposited PHJ cells is that the absence of solubility requirements allows the design of simpler donor structures of lower molecular weight that are generally more stable than their soluble versions.

Oligothiophenes (nTs) have been widely used as p-type organic semiconductors in organic (opto)electronics devices such as OFETs, OLEDs and OSCs. ${ }^{11-14}$ While the maximum PCE of cells based on pure nTs has remained at a modest level for a long time, ${ }^{15-17}$ a PCE of $1.50 \%$ was recently reported for a hybrid co-evaporated cell with $6 \mathrm{~T}$ as donor, $\mathrm{C}_{60}$ as acceptor and an exciton-blocking buffer layer. ${ }^{18}$

Bäuerle, Leo and co-workers have intensively investigated various series of nTs end-capped with electron-accepting dicyanovinyl (DCV) groups as donor materials in multi-layer PHJ cells prepared by vacuum-process. ${ }^{19}$ In particular they analyzed the effects of alkyl substituents on various series of DCV-end-capped nTs and highlighted the key role of the number and position of short alkyl groups on the crystallographic structure and OPV performance of the donor material. Thus, a highest PCE of $6.90 \%$ has been reported for an optimized multi-layered cell with a $5 \mathrm{~T}$ with a median 3,4-dimethylthiophene unit. ${ }^{9}$

Quaterthiophene (4T) has been identified as an interesting p-type organic semiconductor already in $1990 .{ }^{20} \mathrm{In}$ fact, together with other short-chain oligothiophenes, ${ }^{21} 4 \mathrm{~T}$ could represent an interesting starting point for the design of OPV materials combining low molecular weight and structural simplicity. ${ }^{1 h, 22}$ 
<smiles>CCC1(CC)c2cc(-c3ccc(C=C(C#N)C#N)s3)sc2-c2sc(-c3ccc(C=C(C#N)C#N)s3)cc21</smiles>

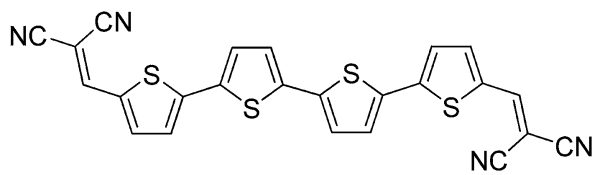

2

Chart 1 Molecular structures of the target compound 1 and the openchain reference compound 2 .

We have extensively investigated the rigidification of $\pi$ conjugated thiophene-based systems by covalent bridging and demonstrated that this approach represents a powerful tool for the control of their electronic properties. ${ }^{23}$ Recently the extension of this approach to the electron-withdrawing end-group of small push-pull molecular donors has shown to significantly improve their performance in OPV cells. ${ }^{24}$

In this work, we report on the synthesis and characterization of a DCV-end-capped $4 \mathrm{~T}$ in which the inner 2,2'-bithiophene block is rigidified by covalent bridging (1) (Chart 1). Note that quaterthiophene derivatives with similar structures have been previously reported as active materials for n-type organic fieldeffect transistors ${ }^{25}$ and OPV. ${ }^{26}$ The optical, electrochemical and thermal properties of titled compound $\mathbf{1}$ have been investigated and the crystallographic structure of a single crystal has been analyzed. The potential of compound $\mathbf{1}$ as donor material has been evaluated stepwise, as already reported, ${ }^{27}$ first on vacuumprocessed bi-layer $\mathrm{PHJ}$ and then on co-evaporated $\mathrm{BHJ}$ using $\mathrm{C}_{60}$ as acceptor. The results are discussed in terms of structureproperties relationships using the open-chain compound 2 as reference.

\section{Results and discussion}

The reference compound 2 (ref. $19 \mathrm{~b}$ ) and 4,4-diethyl- $4 H$-cyclopenta[2,1- $\left.b: 3,4-b^{\prime}\right]$ dithiophene 3 (ref. 28) were prepared according to the literature. The two short ethyl chains of 3 were introduced to increase the solubility of the target compound 1 while still allowing intermolecular interactions. The synthesis of $\mathbf{1}$ is described in Scheme 1. Lithiation of $\mathbf{3}$ with $n$-butyllithium and subsequent quenching with trimethylstannyl chloride gave the bis(stannyl) reagent 4 . A twofold Stille cross-coupling ${ }^{29}$ with 2-((5-bromothiophen-2-yl)methylene)malononitrile 5 (ref. 19c) led to the target compound 1. However, as shown by mass spectrometry, this compound contains traces of a sexithiophene homologue by-product difficult to separate and resulting from an undesired homocoupling reaction of $\mathbf{4}$ followed by a double Stille reaction with 5. In order to circumvent this problem, we used an alternative route based on the Stille coupling of 5-bromothiophene-2-carbaldehyde 6 with 4 . In that case, the sexithiophene by-product is separated by column chromatography and the bis-aldehyde product 7 is obtained in $87 \%$ yield. Finally, a Knoevenagel condensation of 7 with malonodinitrile
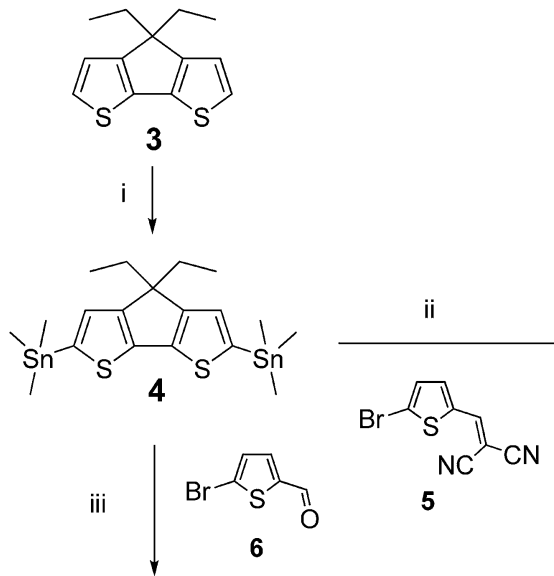

5

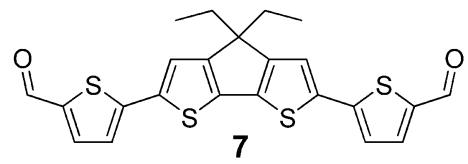

iv
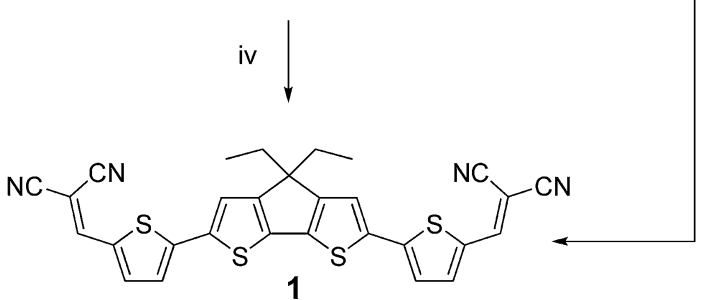

Scheme 1 Synthesis of compound 1. Reagents and conditions: (i) $n$ BuLi (2.5 eq.), $\mathrm{Me}_{3} \mathrm{SnCl}$ (2.5 eq.), THF, $-78^{\circ} \mathrm{C}$ (96\%); (ii) $\mathrm{Pd}\left(\mathrm{PPh}_{3}\right)_{4}(0.05$ eq.), DMF, $80{ }^{\circ} \mathrm{C}$; (iii) $\mathrm{Pd}\left(\mathrm{PPh}_{3}\right)_{4}$ (0.05 eq.), $\mathrm{DMF}, 80{ }^{\circ} \mathrm{C}(87 \%)$; (iv) $\mathrm{CH}_{2}(\mathrm{CN})_{2}$ (3 eq.), $\mathrm{Et}_{3} \mathrm{~N}$ (0.1 eq.), $\mathrm{CHCl}_{3}(94 \%)$

yielded the target compound $\mathbf{1}$ (93\%). The presence of the two ethyl chains on compound 1 significantly increases its solubility compared to 2 thus allowing its purification by column chromatography.

Single crystals suitable for X-ray diffraction were grown by the slow evaporation of a $\mathrm{CHCl}_{3}$ solution of compound 1 . The later crystallizes in the triclinic space group $P \overline{1}$ with one independent molecule of $\mathbf{1}$ and one independent molecule of $\mathrm{CHCl}_{3}$ per asymmetric unit (see ESI, Table S1, Fig. S7-S9†). Fig. 1 shows that the two terminal thiophene rings of $\mathbf{1}$ adopt two different conformations, syn or anti, relatively to the central bridged unit with the DCV units pointing toward opposite directions with respect to the main axis of the $4 \mathrm{~T}$ backbone. As generally observed, the DCV groups adopt a cis conformation relatively to the sulphur atom of their vicinal thiophene units. ${ }^{19 b, 24 b}$

Except for the two ethyl chains of the methylene bridge perpendicularly to the main molecular plane, molecule $\mathbf{1}$ is almost planar with a $0.03 \AA$ RMS deviation from planarity. As expected, the bridged bithiophene core is fully planar. A slight deviation from planarity results from a small dihedral angle C12-C13-C14-C15 of $5.6^{\circ}$ between the bridged core and the terminal thiophene unit in syn conformation whereas a dihedral angle C3-C4-C5-C6 of $1.1^{\circ}$ is observed for the thiophene ring in anti conformation. 

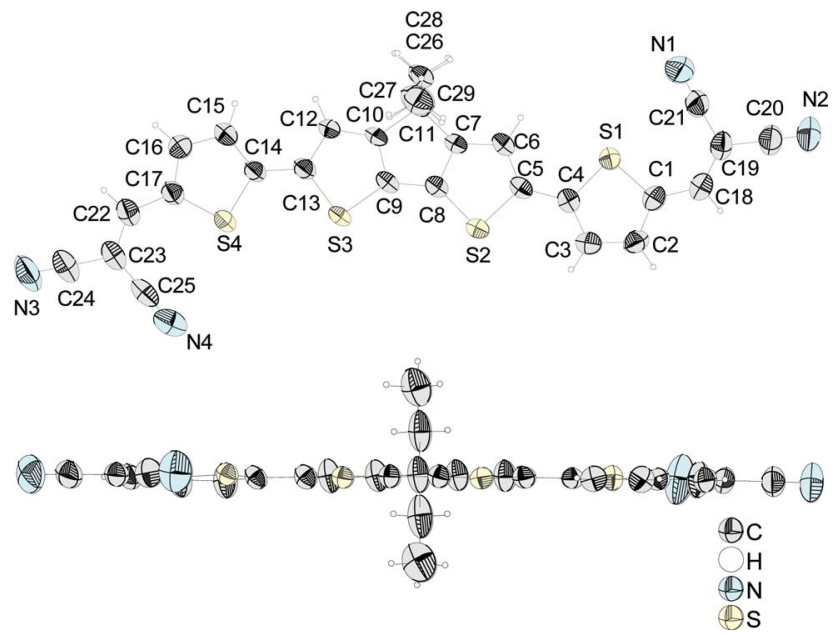

Fig. 1 ORTEP views of compound 1 with ellipsoids drawn at 50\% probability level.

Fig. 2 shows that molecules $\mathbf{1}$ are regularly stacked along the $a$ axis with a parallel orientation and a head-to-tail arrangement with respect to the diethyl chains. The short mean intermolecular distances inside the column $d_{1}=3.577 \AA$ and $d_{2}=3.541 \AA$ are consistent with a compact packing associated with $\pi-\pi$ stacking interactions. Detailed analysis of the structure reveals multiple $S \cdots S$ distances shorter than twice the van der Waals radius of sulphur $(3.70 \AA)$. For instance the sulphur atoms of the bridged blocks in a stack are distant of 3.600(1) $\AA\left(d_{\mathrm{S} 2-\mathrm{S}^{\prime}}\right)$ and 3.646(1) $\AA$ ( $\left(d_{\mathrm{S} 3-\mathrm{S}^{\prime}}\right)$. On the other hand, an intermolecular $\mathrm{S} \cdots \mathrm{S}$ distance $d_{\mathrm{S} 2-\mathrm{S} 4^{\prime}}$ of 3.650(1) $\AA$ is observed between a sulphur atom of a bridged bithiophene and a terminal thiophene. Molecules 1 form an almost layered structure approximately in the $b c$ plane. Indeed, molecules $\mathbf{1}$ are nearly coplanar with small

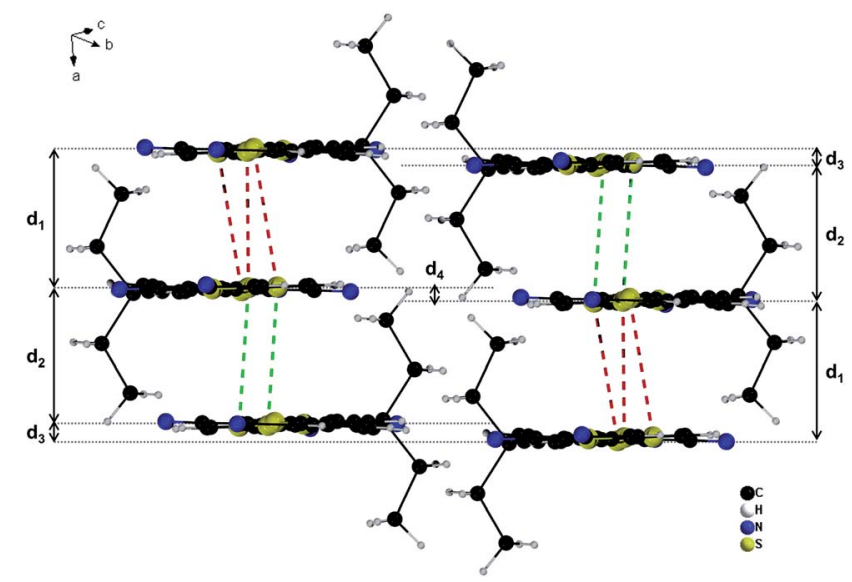

Fig. 2 Molecular packing of molecules 1 along the a axis showing the mean intermolecular distances $\left(d_{1}=3.577 \AA\right.$ and $\left.d_{2}=3.541 \AA\right)$ and $S$... S contacts (green and red dashed lines) shorter than the sum of van der Waals radii of sulphur atom (3.70 $\AA$ ) inside a column. The offsets of coplanarity between neighbouring molecules $\left(d_{3}=0.531 \AA\right.$ and $d_{4}=$ $0.496 \AA)$ are also indicated. $\left(\mathrm{CHCl}_{3}\right.$ molecules have been omitted for clarity). offsets of coplanarity of $d_{3}=0.531 \AA$ and $d_{4}=0.496 \AA$ between neighbouring molecules of different columns.

The view in the $b c$ plane shows the overlap of two neighbouring molecules in the stack (Fig. 3). Again, a head-to-tail organization is clearly apparent. Two consecutive molecules of a column are slightly shifted along and perpendicular to the main molecular axis so that the two related bridged units do not overlap perfectly although short $S \cdots S$ intermolecular contacts exist as already mentioned. Overlaps between terminal thiophene rings and DCV units are observed with some short intermolecular $\mathrm{C} \cdots \mathrm{C}$ distances $\left(d_{\mathrm{C} 4-\mathrm{C} 23^{\prime}}=3.759(6) \AA, d_{\mathrm{C} 4-\mathrm{C} 22^{\prime}}=\right.$ $3.590(6) \AA$ and $\left.d_{\mathrm{C} 3-\mathrm{C} 22^{\prime}}=3.590(7) \AA\right)$ in agreement with the existence of $\pi-\pi$ stacking. It is worth noting that the perpendicular orientation of the two ethyl chains relatively to the plane of the conjugated system does not prevent close molecular packing thus allowing intermolecular electronic coupling in the stacks.

$\mathrm{C}-\mathrm{H} \cdots \mathrm{N}$ hydrogen bonding interactions are represented in Fig. 4. In fact, short intermolecular $\mathrm{N} \cdots \mathrm{H}$ contacts are observed between nitrogen atoms of the DCV nitrile group and vinylic hydrogen atoms of $\operatorname{DCV}\left(d_{\mathrm{N} 3-\mathrm{H} 18}=2.732(7) \AA\right.$ and $d_{\mathrm{N} 2-\mathrm{H} 22}$ $2.398(6) \AA)$ or thiophenic hydrogen atoms of the bridged bithiophene $\left(d_{\mathrm{N} 1-\mathrm{H} 12}=2.480(6) \AA\right)$. Such hydrogen bonding

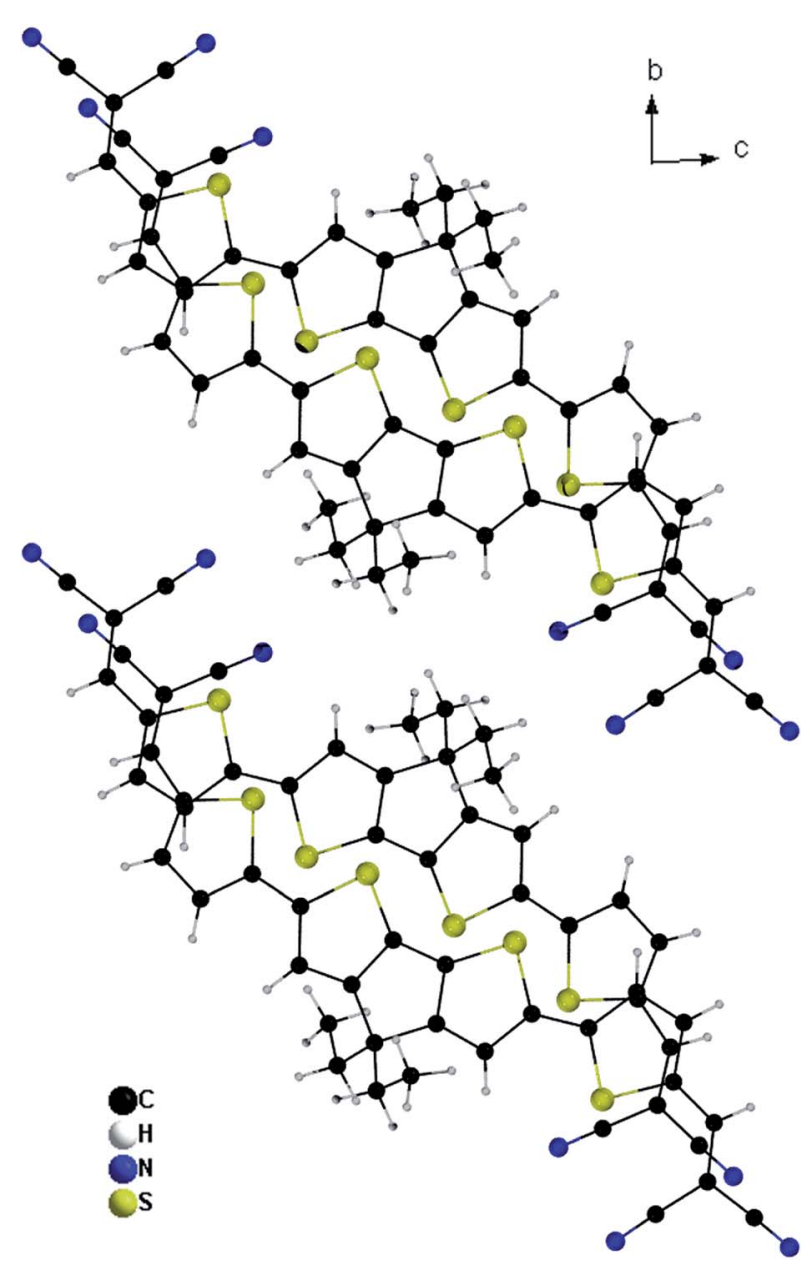

Fig. 3 Overlap of molecules 1 viewed in the bc plane. 


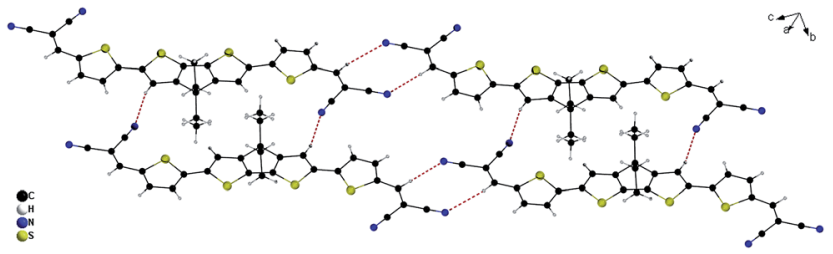

Fig. 4 Short $\mathrm{N} \cdots \mathrm{H}$ intermolecular contacts (red dashed lines) between molecules of 1 .

interactions consolidate the crystal packing in a 2D network as observed for $2 .^{19 b}$

The thermal properties of $\mathbf{1}$ have been analyzed by differential scanning calorimetry (DSC) and thermogravimetric analysis (TGA). The first DSC trace shows a sharp endothermic peak with an onset at $303{ }^{\circ} \mathrm{C}$ corresponding to the melting point of 1 (Fig. S10†). At higher temperatures, the DSC trace exhibits an intense exothermic peak with an onset at $384{ }^{\circ} \mathrm{C}$ assigned to the beginning of decomposition. The high thermal stability of 1 was confirmed by TGA which indicates a decomposition temperature $T_{\mathrm{d}}$, defined at $5 \%$ weight loss, of $368{ }^{\circ} \mathrm{C}$ in close agreement with DSC data.

Thermal evaporation of $\mathbf{1}$ under vacuum readily affords homogenous thin-films without any sign of decomposition as confirmed by MALDI-TOF and UV-Vis analysis of a re-dissolved film. Vacuum-deposited thin-films of 1 or 2 on glass at room temperature with $15 \mathrm{~nm}$ or $80 \mathrm{~nm}$ thickness have been analyzed by X-ray diffraction (XRD). In our conditions (see ESI $\dagger$ ), the absence of diffraction peaks, in each case, suggests the very low degree of crystallinity of the films. The same behaviour has been observed for $115 \mathrm{~nm}$ thick films of 1 and 2 vacuum-deposited on ITO substrates recovered by PEDOT-PSS.

The electronic and electrochemical properties of $\mathbf{1}$ have been analyzed by UV-Vis spectroscopy and cyclic voltammetry. The absorption spectrum of compound 1 in $\mathrm{CH}_{2} \mathrm{Cl}_{2}$ exhibits a broad band extending from 450 to $700 \mathrm{~nm}$ attributed to a $\pi-\pi^{*}$ transition with an absorption maximum $\lambda_{\max }$ at $581 \mathrm{~nm}$ (Fig. 5, top). Comparison with compound 2 shows that the bridging of the central 2,2'-bithiophene block leads to a $65 \mathrm{~nm}$ bathochromic shift of $\lambda_{\max }$, in agreement with a reduction of the HOMOLUMO gap, while the molar extinction coefficient $\varepsilon$ increases from 66400 to $80300 \mathrm{~L} \mathrm{~mol}^{-1} \mathrm{~cm}^{-1}$. The absorption spectrum of a thin film of 1 evaporated on glass presents a $28 \mathrm{~nm}$ red shift of $\lambda_{\max }$ and a broadening of the absorption band compared to the solution spectrum (Fig. 5, bottom). The well-defined shoulder observed at $c a .660 \mathrm{~nm}$ is attributed to intermolecular $\pi$-interactions in the solid state. Optical band gaps of 1.68 and $1.82 \mathrm{eV}$ have been estimated respectively from the long wavelength absorption edge of thin-films of 1 and 2. Consistently with the results obtained in solution, the absorption coefficient of the films increases from $1.59 \times 10^{5} \mathrm{~cm}^{-1}$ for 2 to $1.83 \times 10^{5} \mathrm{~cm}^{-1}$ for 1 .

Cyclic voltammetry was performed in $\mathrm{CH}_{2} \mathrm{Cl}_{2}$ in the presence of $\mathrm{Bu}_{4} \mathrm{NPF}_{6}$ as supporting electrolyte. The cyclic voltammogram (CV) of 1 exhibits a first one-electron reversible oxidation wave with an anodic peak potential $E_{\mathrm{pa}}^{1}$ at $0.64 \mathrm{~V} v s . \mathrm{Fc} / \mathrm{Fc}^{+}$, associated
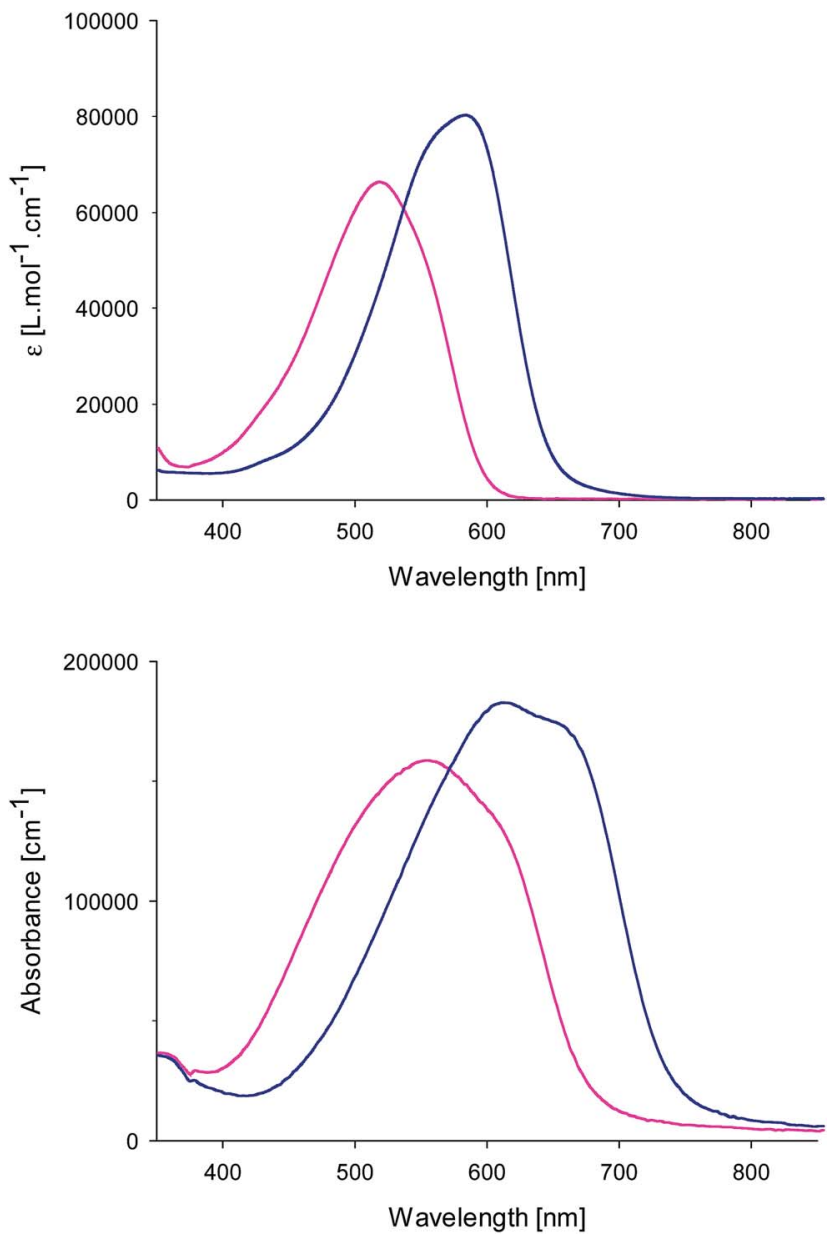

Fig. 5 Absorption spectra of compound 1 (blue line) and 2 (pink line) in $\mathrm{CH}_{2} \mathrm{Cl}_{2}$ solution (top) and as films of $15 \mathrm{~nm}$ thickness evaporated on glass (bottom).

to a stable radical cation, and a second irreversible oxidation wave at $E_{\mathrm{pa}}^{2}$ at $1.21 \mathrm{~V}$ vs. $\mathrm{Fc} / \mathrm{Fc}^{+}$(Fig. S11 and S12†). An irreversible reduction wave is observed with a cathodic peak potential $\left(E_{\mathrm{pc}}^{1}\right)$ at $-1.33 \mathrm{~V}$. Comparison of the first standard oxidation potentials of 1 and $2,{ }^{19 b}$ shows that the bridging leads to a significant negative shift from $0.84 \mathrm{~V}$ to $0.60 \mathrm{~V}$ associated with an increase of the HOMO level, whereas no significant change is observed on the reduction potential.

Theoretical calculations based on density functional methods were performed with the Gaussian 09 program for compounds 1 and 2. ${ }^{30}$ Becke's three-parameter ${ }^{31}$ gradient-corrected functional (B3LYP) with the 6-311G(d,p) basis set were used to optimize their geometries and to compute their electronic structures at the observed minima. Except the two ethyl chains perpendicular to the conjugated system, molecule 1 shows a planar structure with the two terminal thiophene rings in an anti conformation relatively to the central bridged bithiophene core and the two DCV moieties in syn conformation relatively to the sulphur atom of the vicinal thiophene.

Fig. 6 compares the HOMO and LUMO energy levels of 1 and 2. The HOMO and LUMO of both molecules display typical aromatic and quinoid characters, respectively, with a full 


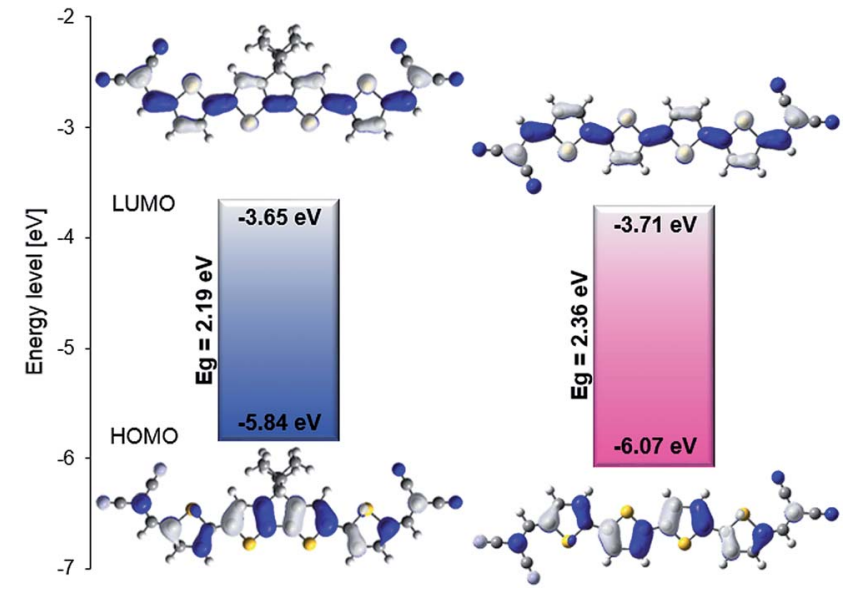

Fig. $6 \mathrm{HOMO}$ and LUMO energy levels and their representations for 1 and 2 after optimization with Gaussian 09 at the B3LYP/6-311G (d,p) level of theory.

delocalization on the whole $\pi$-conjugated backbone. The bridging of 1 produces a significant increase of the HOMO level $(+0.23 \mathrm{eV})$ compared to 2 , in full agreement with the $\mathrm{CV}$ results. On the other hand, the LUMO level of $\mathbf{1}$ is increased by $0.06 \mathrm{eV}$. These combined results lead to a $0.17 \mathrm{eV}$ reduction of HOMOLUMO gap for the bridged system in agreement with optical data.

The photovoltaic performance of compound $\mathbf{1}$ as donor material for OPV has been evaluated on simple bi-layer PHJ cells using $\mathrm{C}_{60}$ as acceptor material (Fig. 7, top). Cells of $27 \mathrm{~mm}^{2}$ active area were fabricated by successive thermal evaporations of donor $1,20 \mathrm{~nm}$ of $\mathrm{C}_{60}$ and $150 \mathrm{~nm}$ of aluminum on ITO substrates pre-coated with a $40 \mathrm{~nm}$ layer of spin-cast PEDOTPSS (see ESI†). Table 1 lists the photovoltaic parameters of the devices under AM 1.5 simulated solar illumination.

Comparison of the data of entries 1-3 shows that the maximum values of the short-circuit current density $\left(J_{\text {sc }}\right)$ and PCE values are obtained with a donor layer of $15 \mathrm{~nm}$ thickness (d). This value could represent the best trade-off between the absorbance of the donor layer, exciton diffusion and charge collection. ${ }^{32}$ With this thickness, the best cell gives a $J_{\mathrm{sc}}$ of $5.07 \mathrm{~mA} \mathrm{~cm}{ }^{-2}$ and a PCE of $2.82 \%$ (Fig. 7 , middle). Under identical conditions, compound 2 gives a $J_{\mathrm{sc}}$ of $1.74 \mathrm{~mA} \mathrm{~cm}^{-2}$ and a PCE of $0.51 \%$. The difference in $J_{\text {sc }}$ between compounds 1 and 2 can be related to the better absorption properties of 1 which is also observed on the external quantum efficiency (EQE) spectra (Fig. 7, bottom). The very low fill-factor (FF) recorded for 2 could be related to both hindered charge transport within the active layer and limited charge-transfer at the donor/electrode interface maybe due to a larger extraction barrier related to the deeper HOMO level of $\mathbf{2 .}^{33}$

It is worth noting that in the best conditions, the bridged compound 1 leads to higher values of the open-circuit voltage $\left(V_{\mathrm{oc}}\right)$ and FF than compound 2. Based on the higher HOMO level of the bridged donor, a decrease of $V_{\mathrm{oc}}$ could have been expected. ${ }^{34}$ In fact, such concomitant increase of $V_{\text {oc }}$ and FF caused by the covalent bridging of the donor has already been observed
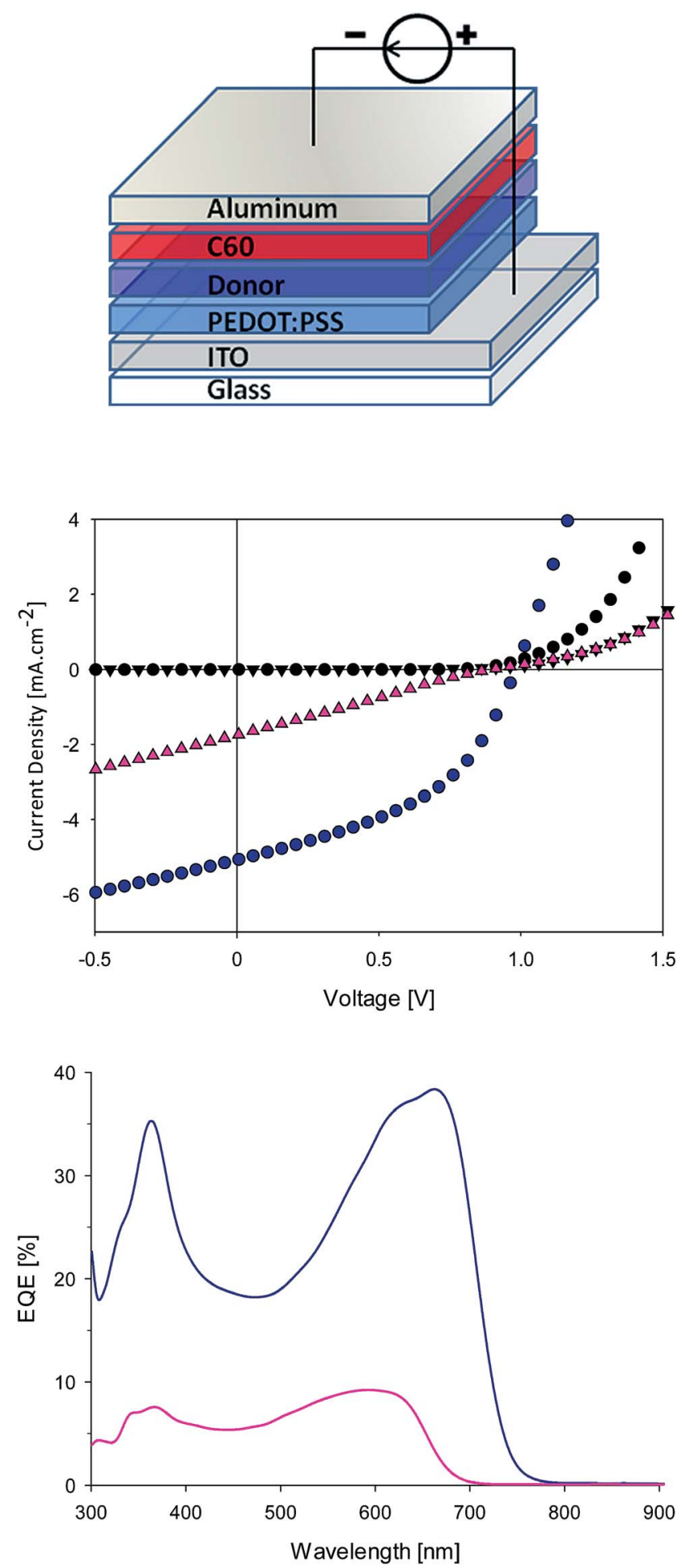

Fig. 7 Top: architecture of bi-layer PHJ solar cells. Middle: current density vs. voltage curves of bi-layer PHJ cells ITO/PEDOT-PSS/1 (circles) or 2 (triangles) $(15 \mathrm{~nm}) / \mathrm{C}_{60}(20 \mathrm{~nm}) / \mathrm{Al}(150 \mathrm{~nm})$ in the dark (in black) and under AM 1.5 simulated solar light $\left(80 \mathrm{~mW} \mathrm{~cm}^{-2}\right.$ ) (in colour). Bottom: external quantum efficiency of the best bi-layer $\mathrm{PHJ}$ cells under monochromatic irradiation. Blue line: 1, pink line: 2 . 
Table 1 Photovoltaic parameters of bi-layers donor/C 60 under AM 1.5 simulated solar illumination with an average power intensity of ca. $80 \mathrm{~mW} \mathrm{~cm}^{-2 a, b}$

\begin{tabular}{lllllr}
\hline Entry & Donor & $d(\mathrm{~nm})$ & $V_{\mathrm{oc}}(\mathrm{V})$ & $J_{\mathrm{sc}}\left(\mathrm{mA} \mathrm{cm}^{-2}\right)$ & FF \\
\hline 1 & 1 & 10 & $0.85(0.83)$ & $4.00(3.75)$ & $0.44(0.43)$ \\
2 & 1 & 15 & $0.97(0.94)$ & $5.07(4.88)$ & $0.45(0.41)$ \\
3 & 1 & 20 & $0.95(0.94)$ & $4.19(3.55)$ & $0.39(0.36)$ \\
4 & 2 & 15 & $0.88(0.86)$ & $1.74(1.50)$ & $0.25(0.24)$
\end{tabular}

${ }^{a}$ General structure of the bi-layer solar cells ITO/PEDOT:PSS $(40 \mathrm{~nm}) /$ donor/C $\mathrm{C}_{60}(20 \mathrm{~nm}) / \mathrm{Al}(150 \mathrm{~nm}) .{ }^{b}$ Data in brackets are the average values measured on 18, 37, 25 and 22 cells respectively for entries 1, 2, 3 and 4; data in bold are the best of each series (see also ESI).

and attributed to changes in the interfacial dipoles at the donor/ electrode interface and/or at the donor/acceptor interface, ${ }^{24 c}$ further work is needed to clarify this question.

Fig. 7 (bottom) shows the EQE action spectrum of the best bilayer PHJ devices based on $\mathbf{1}$ and $\mathbf{2}$ under monochromatic irradiation. The spectrum of 2 shows small peaks around 360 $\mathrm{nm}$ associated with the contribution of $\mathrm{C}_{60}$ followed by a broad band extending from 450-700 nm with a maximum of $c a .8 .0 \%$ corresponding to the absorption of the donor. As expected, the spectrum of the cell based on the bridged compound 1 shows a strong enhancement of the photoresponse with a first maximum of $35 \%$ at $\sim 360 \mathrm{~nm}$ due to $\mathrm{C}_{60}$ and a second maximum of $38 \%$ at $\sim 660 \mathrm{~nm}$. On the other hand, a large extension of photo-response toward longer wavelengths up to $750 \mathrm{~nm}$ is observed, in agreement with the reduced band gap of the bridged donor.

The hole mobility $\left(\mu_{\mathrm{h}}\right)$ of donor $\mathbf{1}$ has been estimated on hole only devices using the space-charge-limited conduction (SCLC) method (see ESI $\dagger$ ). The obtained value $\mu_{\mathrm{h}}=3.4 \times 10^{-5} \mathrm{~cm}^{2} \mathrm{~V}^{-1} \mathrm{~s}^{-1}$ is comparable to the values found on many small molecular donors. ${ }^{1 g}$ In the same conditions as for $\mathbf{1}$, the determination of the hole mobility of reference compound 2 leads to a value of $2 \times 10^{-6} \mathrm{~cm}^{2} \mathrm{~V}^{-1} \mathrm{~s}^{-1}$. The improved electronic charge transport properties of titled compound 1 can contribute to its better OPV performance. On the other hand, these results show also that, while increasing the solubility of compound $\mathbf{1}$, the introduction of ethyl substituents does not prevent efficient charge transport in agreement with X-ray data displaying strong intermolecular $\pi$-interactions in the solid state.

In previous work on the open-chain donor 2, a PCE of $1.20 \%$ with a $J_{\mathrm{sc}}$ of $2.90 \mathrm{~mA} \mathrm{~cm}{ }^{-2}$ was reported for an inverted cell of composition: ITO/C $60(15 \mathrm{~nm}) / 2(6 \mathrm{~nm}), 9,9-\mathrm{bis}[4-(N, N$-bisbiphenyl-4-ylamino)phenyl]-9H-fluorene (BPAPF) $(5 \mathrm{~nm}) / \mathrm{BPAPF}$ p-doped with NDP9 (a proprietary dopant) (50 nm)/NDP9 (1 $\mathrm{nm}) / \mathrm{Au}(50 \mathrm{~nm}) .{ }^{19 b}$ More recently the same group reported a cell of similar architecture with a $6 \mathrm{~mm}^{2}$ area in which the planar heterojunction was replaced by a layer of co-evaporated donor 2 and $\mathrm{C}_{60}(20 \mathrm{~nm})$. This multi-layer cell delivered a $J_{\mathrm{sc}}$ of $6.49 \mathrm{~mA}$ $\mathrm{cm}^{-2}$ with a PCE of $3.00 \% .{ }^{35}$ Comparison of these results with those of Table 1 shows that the introduction of buffer layers of optimized thickness and doping together with the fabrication of a $\mathrm{BHJ}$ cell structure can greatly improve the PV performance of devices based on donor 2 .
In order to further investigate the potential of donor $\mathbf{1}$, various experiments aiming at optimizing the device have been performed. Attempts to apply thermal treatment to the bi-layer cells remained unsuccessful and only led to a degradation of the
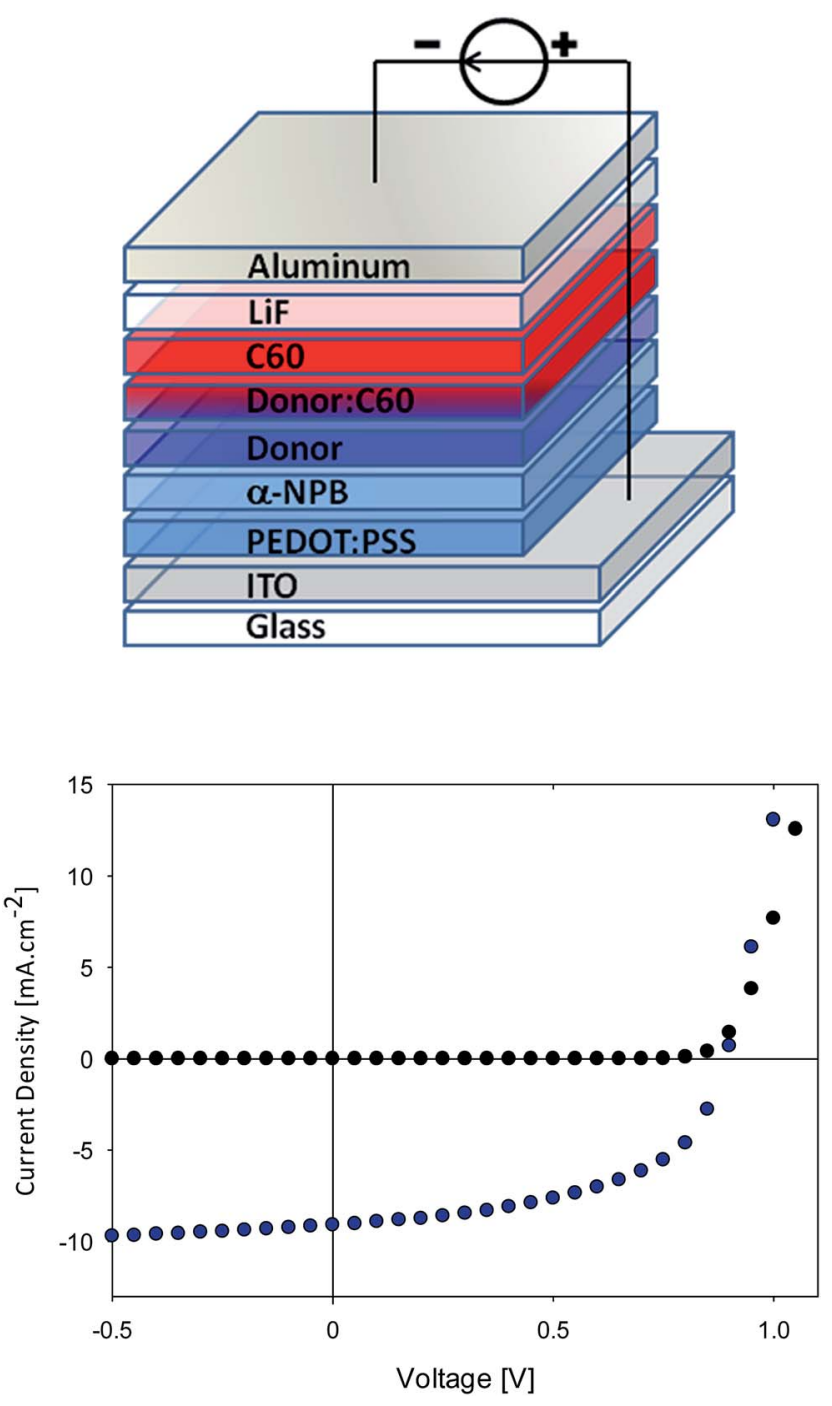

Fig. 8 Top: architecture of a gradiently doped $\mathrm{BHJ}$ device: ITO/ PEDOT-PSS/ $\alpha-N P B / 1 / 1: C_{60}(45$ to $70 \%) / C_{60} / \mathrm{LiF} / \mathrm{Al}$. Bottom: current density vs. voltage curves in the dark (black circles) and under AM 1.5 simulated solar light (100 $\mathrm{mW} \mathrm{cm}^{-2}$ ) (blue circles). 
performance. More advanced $\mathrm{BHJ}$ cells have been prepared by co-evaporating 1 and $\mathrm{C}_{60}$ with a spatial gradient of concentration and by inserting a hole extraction layer of 4,4'-bis[ $N$-(1naphtyl)- $N$-phenylamino]biphenyl $(\alpha-\mathrm{NPB})$ at the anode and LiF at the cathode, as described in Fig. $8 .^{22 b}$

The cells of $28 \mathrm{~mm}^{2}$ area have been optimized by: (i) varying the thickness of $\alpha$-NPB, (ii) inserting an additional layer of pure 1 before co-evaporation with $\mathrm{C}_{60}$ and (iii) controlling the gradient of co-evaporation while maintaining a $40: 60$ ratio of 1 and $\mathrm{C}_{60}$. The best results have been obtained with a device with the following of structure: ITO/PEDOT:PSS (40 nm)/ $\alpha$-NPB (15 $\mathrm{nm}) / \mathbf{1}(5 \mathrm{~nm}) / \mathbf{1}: \mathrm{C}_{60}(45$ to $70 \%)(30 \mathrm{~nm}) / \mathrm{C}_{60}(30 \mathrm{~nm}) / \mathrm{LiF}(1.2$ $\mathrm{nm}) / \mathrm{Al}(100 \mathrm{~nm})$. The current density $v s$. voltage curves of three cells of this type showed a $\mathrm{PCE}_{\max }$ of $4.30 \%$ (average value of $4.0 \%$ ) associated with $V_{\mathrm{oc}}, J_{\mathrm{sc}}$ and FF values of $0.89 \mathrm{~V}, 9.12 \mathrm{~mA}$ $\mathrm{cm}^{-2}$ and 0.53 , respectively (Fig. 8). As expected, the corresponding EQE spectrum exhibits an enhanced photocurrent with a plateau of $\sim 52 \%$ in the $570-640 \mathrm{~nm}$ range (Fig. S15 $\dagger$ ).

\section{Conclusions}

A covalently bridged $\alpha, \omega$-bis(dicyanovinyl)quaterthiophene with a central cyclopenta[2,1- $\left.b: 3,4-b^{\prime}\right]$ dithiophene has been synthesized and purified by standard column chromatography thanks to the improved solubility imparted by ethyl chains introduced on the methylene bridge. Comparison of the electrochemical and optical data to those of an open-chain analogue shows that the bridging of the central 2,2'-bithiophene core produces a significant reduction of the band gap associated with a raising of $c a .0 .15 \mathrm{eV}$ of the HOMO level. X-Ray diffraction analysis of a single crystal reveals a compact structure in which $\pi$-stacked molecules are stabilized by multiple short intermolecular contacts.

The photovoltaic performance of the new donor has been analyzed on basic bi-layer planar hetero-junction cells with $\mathrm{C}_{60}$ as acceptor. In these conditions, the results show that the bridged donor leads at the same time to improved current density, voltage and fill factor and thus to conversion efficiency $c a$. five times larger than that of the open-chain reference compound. In addition, the value of the hole mobility of the new donor is one order of magnitude higher than that of the open-chain compound. The bridged compound has been used as donor in hybrid hetero-junction cells based on active layers produced by co-evaporation with $\mathrm{C}_{60}$ under controlled concentration gradient and involving anode and cathode buffer layers. The PCE of $4.30 \%$ obtained under simulated solar light provides a further clear confirmation of the interest of covalent rigidification as a powerful synthetic tool for the design of efficient molecular donors with limited structural complexity. Work aiming at the extension of this approach to other classes of molecular donors is now underway in our laboratory and will be reported in future publications.

\section{Experimental}

All reagents from commercial sources were used without further purification. Reactions were carried out under nitrogen atmosphere unless otherwise stated. Solvents were dried and purified using standard techniques. Flash chromatography was performed with analytical-grade solvents using Aldrich silica gel (technical grade, pore size $60 \AA$, 230-400 mesh particle size). Flexible plates ALUGRAM® Xtra SIL G UV ${ }_{254}$ from MACHEREYNAGEL were used for TLC. Compounds were detected by UV irradiation (Bioblock Scientific) or staining with $I_{2}$, unless otherwise stated. NMR spectra were recorded with a Bruker AVANCE III $300\left({ }^{1} \mathrm{H}, 300 \mathrm{MHz}\right.$ and $\left.{ }^{13} \mathrm{C}, 75 \mathrm{MHz}\right)$. Chemical shifts are given in ppm relative to TMS and coupling constants $J$ in $\mathrm{Hz}$. IR spectra were recorded on a Bruker spectrometer Vertex 70 and UV-Vis spectra with a Perkin-Elmer 950 spectrometer. Matrix Assisted Laser Desorption/Ionization was performed on MALDI-TOF MS BIFLEX III Bruker Daltonics spectrometer using dithranol as matrix.

Cyclic voltammetry was performed in $0.10 \mathrm{M} \mathrm{Bu} \mathrm{BPF}_{6} /$ $\mathrm{CH}_{2} \mathrm{Cl}_{2}$ (HPLC grade). Solutions were degassed by nitrogen bubbling prior to each experiment. Experiments were carried out in a one-compartment cell equipped with platinum electrodes and a saturated calomel reference electrode (SCE) using a Biologic SP-150 potentiostat with positive feedback compensation. Elemental analyses were performed with a thermo-electron instrument (FLASH 2000, Thermo Scientific). DSC and TGA were performed with TA Instruments Q20 and Q500 respectively.

\section{Synthesis}

Compounds $2,{ }^{19 b} 3$ (ref. 28) (see ESI $\dagger$ ) and 5 (ref. 19c) have been synthesized following reported procedures.

(4,4-Diethyl-4H-cyclopenta[1,2-b:5,4- $\left.b^{\prime}\right]$ dithienyl-2,6-diyl)bis(trimethylstannane) 4. $n$-BuLi (1.6 M in hexanes, $5.73 \mathrm{~mL}, 9.17$ $\mathrm{mmol}$ ) was added dropwise to $3(860 \mathrm{mg}, 3.67 \mathrm{mmol}$ ) in $25 \mathrm{~mL}$ of anhydrous THF cooled to $-78{ }^{\circ} \mathrm{C}$. The mixture was then warmed up to room temperature and further stirred for $2 \mathrm{~h}$. The reaction mixture was cooled to $-78{ }^{\circ} \mathrm{C}$ and $\mathrm{Me}_{3} \mathrm{SnCl}(1 \mathrm{M}$ in hexanes, $9.17 \mathrm{~mL}, 9.17 \mathrm{mmol}$ ) was added. The reaction mixture was warmed to room temperature and stirred for $14 \mathrm{~h}$. Water and $\mathrm{CH}_{2} \mathrm{Cl}_{2}$ were added. The organic phase was separated and washed with a saturated $\mathrm{NaHCO}_{3}$ solution and brine, dried with $\mathrm{MgSO}_{4}$ and concentrated under reduced pressure yielding 4 (1.98 g, $3.54 \mathrm{mmol}, 96 \%)$ as a slightly brown solid. ${ }^{1} \mathrm{H}$ NMR (300 $\left.\mathrm{MHz}, \mathrm{CDCl}_{3}, \delta\right): 6.94(\mathrm{~s}, 2 \mathrm{H}), 1.87(\mathrm{q}, J=7.4,4 \mathrm{H}), 0.64(\mathrm{t}, J=7.4$, $6 \mathrm{H}), 0.37$ (s, 18H).

5,5'-(4,4-Diethyl-4H-cyclopenta[1,2-b:5,4- $\left.b^{\prime}\right]$ dithienyl-2,6-diyl)dithiophene-2-carbaldehyde 7. A mixture of 4 (1.00 g, 1.79 $\mathrm{mmol})$, 5-bromothiophene-2-carbaldehyde 6 (751 mg, $439 \mathrm{~mL}$, $3.93 \mathrm{mmol}$ ) and tetrakis(triphenylphosphine)palladium(0) (103 $\mathrm{mg}, 0.09 \mathrm{mmol}$ ) in $40 \mathrm{~mL}$ of degassed DMF was stirred at $80{ }^{\circ} \mathrm{C}$ for $14 \mathrm{~h}$. After cooling, water and $\mathrm{CH}_{2} \mathrm{Cl}_{2}$ was added. The organic phase was separated and washed with brine, dried with $\mathrm{MgSO}_{4}$ and concentrated under reduced pressure. The crude oil was purified by column chromatography on silica gel (eluent: $\mathrm{CH}_{2} \mathrm{Cl}_{2}$-petroleum ether $1: 1$ to $\mathrm{CH}_{2} \mathrm{Cl}_{2}$ ) yielding 7 (710 mg, 1.56 mmol, 87\%) as a red powder. mp $214{ }^{\circ} \mathrm{C}$ (onset DSC). ${ }^{1} \mathrm{H}$ NMR $\left(300 \mathrm{MHz}, \mathrm{CDCl}_{3}, \delta\right): 9.85(\mathrm{~s}, 2 \mathrm{H}), 7.66(\mathrm{~d}, J=4.0,2 \mathrm{H}), 7.24(\mathrm{~d}, J=$ $4.0,2 \mathrm{H}), 7.21(\mathrm{~s}, 2 \mathrm{H}), 1.96(\mathrm{q}, J=7.4,4 \mathrm{H}), 0.65(\mathrm{t}, J=7.4,6 \mathrm{H}) .{ }^{13} \mathrm{C}$ 
NMR (75 MHz, $\mathrm{CDCl}_{3}, \delta$ ): 182.37 (s), 159.39 (s), 147.94 (s), 141.19 (s), 138.45 (s), 137.65 (s), 137.48 (s), 123.48 (s), 120.56 (s), 55.67 (s), 30.30 (s), 9.27 (s). IR (neat): $\nu=1645 \mathrm{~cm}^{-1}(\mathrm{C}=\mathrm{O})$. HRMS (MALDI-TOF): $\mathrm{m} / \mathrm{z}$ calcd for $\mathrm{C}_{23} \mathrm{H}_{18} \mathrm{O}_{2} \mathrm{~S}_{4}: 454.0190$, found: 454.0197.

2,2'-[(4,4-Diethyl-4H-cyclopenta[1,2-b:5,4- $\left.b^{\prime}\right]$ dithienyl-2,6-diyl)bis(thiene-5,2-diylmethylylidene)]dipropanedinitrile 1. A solution of 7 (400 mg, $0.88 \mathrm{mmol}$ ), malononitrile (175 mg, $2.64 \mathrm{mmol}$ ) and triethylamine ( $9 \mathrm{mg}, 12 \mu \mathrm{L}, 0.09 \mathrm{mmol}$ ) in $100 \mathrm{~mL}$ of $\mathrm{CHCl}_{3}$ was stirred under reflux for $14 \mathrm{~h}$. The reaction mixture was allowed to cool to room temperature and the solvent was rotary evaporated. The residual powder was purified by column chromatography on silica gel (eluent: $\mathrm{CH}_{2} \mathrm{Cl}_{2}$-petroleum ether $3: 1$ to $\mathrm{CH}_{2} \mathrm{Cl}_{2}$ ) yielding 1 (456 mg, $823 \mathrm{mmol}, 94 \%$ ) as a dark blue-green powder. mp $303{ }^{\circ} \mathrm{C}$ (onset DSC). ${ }^{1} \mathrm{H}$ NMR $\left(300 \mathrm{MHz}, \mathrm{CD}_{2} \mathrm{Cl}_{2}, \delta\right): 7.80$ (s, $J=$ $0.6,2 \mathrm{H}), 7.64(\mathrm{~d}, J=4.8,2 \mathrm{H}), 7.37(\mathrm{~s}, 2 \mathrm{H}), 7.31(\mathrm{~d}, J=4.2,2 \mathrm{H})$, $2.00(\mathrm{~d}, J=7.1,4 \mathrm{H}), 0.63(\mathrm{t}, J=7.3,6 \mathrm{H}) .{ }^{13} \mathrm{C} \mathrm{NMR}(75 \mathrm{MHz}$, $\mathrm{CD}_{2} \mathrm{Cl}_{2}, \delta$ ): 160.93 (s), 150.56 (s), 150.30 (s), 141.31 (s), 140.31 (s), 137.86 (s), 133.79 (s), 124.44 (s), 122.26 (s), 115.08 (s), 114.38 (s), 75.88 (s), 56.39 (s), 30.84 (s), 9.38 (s). IR (neat): $\nu=2216 \mathrm{~cm}^{-1}$ $(\mathrm{C} \equiv \mathrm{N})$. UV-Vis $\left(\mathrm{CH}_{2} \mathrm{Cl}_{2}\right): \lambda_{\max }(\varepsilon)=581 \mathrm{~nm}\left(80300 \mathrm{~L} \mathrm{~mol}^{-1}\right.$ $\mathrm{cm}^{-1}$ ). HRMS (EI): $m / z$ calcd for $\mathrm{C}_{29} \mathrm{H}_{18} \mathrm{~N}_{4} \mathrm{~S}_{4}$ : 550.0414, found: 550.0438. Anal. calc. for $\mathrm{C}_{29} \mathrm{H}_{18} \mathrm{~N}_{4} \mathrm{~S}_{4}$ : C, 63.25; H, 3.29; N, 10.17; S, $23.29 \%$; found: C, 62.99; H, 3.18; N, 10.05; S, $23.21 \%$.

\section{Acknowledgements}

The Ministère de la Recherche is acknowledged for the Ph.D. grant to F. Baert. We thank the PIAM of the University of Angers for characterization of organic compounds. Jonhson Mattey is acknowledged for the gift of $\mathrm{PdCl}_{2}$ used for the preparation of $\mathrm{Pd}\left(\mathrm{PPh}_{3}\right)_{4}$ catalyst.

\section{References}

1 For reviews on molecular OSCs see: (a) M. T. Lloyd, J. M. Anthony and G. C. Malliaras, Mater. Today, 2007, 10, 34; (b) J. Roncali, Acc. Chem. Res., 2009, 42, 1719; (c) F. Würthner and K. Meerholz, Chem.-Eur. J., 2010, 16, 9366; (d) B. Walker, C. Kim and T.-Q. Nguyen, Chem. Mater., 2011, 23, 470; (e) Y. Li, Q. Guo, Z. Li, J. Pei and W. Tian, Energy Environ. Sci., 2010, 3, 1427; $(f)$ A. Mishra and P. Bäuerle, Angew. Chem., Int. Ed., 2012, 51, 2020; (g) Y. Lin, Y. Li and X. Zhan, Chem. Soc. Rev., 2012, 41, 4245; (h) J. Roncali, P. Leriche and P. Blanchard, Adv. Mater., 2014, 26, 3821.

2 (a) Z. He, C. Zhong, X. Huang, W.-Y. Wong, H. Wu, L. Chen, S. Su and Y. Cao, Adv. Mater., 2011, 23, 4636; (b) L. Dou, J. You, J. Yang, C.-C. Chen, Y. He, S. Murase, T. Moriarty, K. Emery, G. Li and Y. Yang, Nat. Photon., 2012, 6, 180; (c) Z. He, C. Zhong, S. Su, M. Xu, H. Wu and Y. Cao, Nat. Photon., 2012, 6, 591; (d) J. You, L. Dou, K. Yoshimura, T. Kato, K. Ohya, T. Moriarty, K. Emery, C.-C. Chen, J. Gao, G. Li and Y. Yang, Nat. Commun., 2013, 4, 1446; (e) C. Cabanetos, A. El Labban, J. A. Barteld, J. D. Douglas, W. M. Mateker, J. M. J. Fréchet, M. D. McGehee and P. M. Beaujuge, J. Am. Chem. Soc., 2013, 135, 4656.
3 H. K. H. Lee, Z. Li, I. Constantinou, F. So, S. W. Tsang and S. K. So, Adv. Energy Mater., 2014, DOI: 10.1002/ aenm.201400768.

4 J. Roncali, P. Frère, P. Blanchard, R. de Bettignies, M. Turbiez, S. Roquet, P. Leriche and Y. Nicolas, Thin Solid Films, 2006, 511, 567.

5 (a) Y. Sun, G. C. Welch, W. L. Leong, C. J. Takacs, G. C. Bazan and A. J. Heeger, Nat. Mater., 2011, 11, 44; (b) A. K. K. Kyaw, D. H. Wang, V. Gupta, J. Zhang, S. Chand, G. C. Bazan and A. J. Heeger, Adv. Mater., 2013, 25, 2397; (c) V. Gupta, A. K. K. Kyaw, D. H. Wang, S. Chand, G. C. Bazan and A. J. Heeger, Sci. Rep., 2013, 3, 1965; (d) J. E. Coughlin, Z. B. Henson, G. C. Welch and G. Bazan, Acc. Chem. Res., 2014, 47, 257.

6 (a) J. Zhou, X. Wan, Y. Liu, Y. Zuo, Z. Li, G. He, G. Long, W. Ni, C. Li, X. Su and Y. Chen, J. Am. Chem. Soc., 2012, 134, 16345; (b) J. Zhou, Y. Zuo, X. Wan, G. Long, Q. Zhang, W. Ni, Y. Liu, Z. Li, G. He, C. Li, B. Kan, M. Li and Y. Chen, J. Am. Chem. Soc., 2013, 135, 8484; (c) Y. Chen, X. Wan and G. Long, Acc. Chem. Res., 2013, 46, 2645.

7 Y. Liu, C.-C. Chen, Z. Hong, J. Gao, Y. Yang, H. Zhou, L. Dou, G. Li and Y. Yang, Sci. Rep., 2013, 3, 3356.

8 V. Steinmann, N. M. Kronenberg, M. R. Lenze, S. M. Graf, D. Hertel, K. Meerholz, H. Bürckstümmer, E. V. Tulyakova and F. Würthner, Adv. Energy Mater., 2011, 1, 888.

9 R. Fitzner, E. Mena-Osteritz, A. Mishra, G. Schulz, E. Reinold, M. Weil, C. Körner, H. Ziehlke, C. Elschner, K. Leo, M. Riede, M. Pfeiffer, C. Ulrich and P. Bäuerle, J. Am. Chem. Soc., 2012, 134, 11064.

10 (a) L.-Y. Lin, Y.-H. Chen, Z.-Y. Huang, H.-W. Lin, S.-H. Chou, F. Lin, C.-W. Chen, Y.-H. Liu and K.-T. Wong, J. Am. Chem. Soc., 2011, 133, 15822; (b) Y.-H. Chen, L.-Y. Lin, C.-W. Lu, F. Lin, Z.-Y. Huang, H.-W. Lin, P.-H. Wang, Y.-H. Liu, K.-T. Wong, J. Wen, D. J. Miller and S. B. Darling, J. Am. Chem. Soc., 2012, 134, 13616.

11 F. Garnier, Acc. Chem. Res., 1999, 32, 209.

12 G. Barbarella, M. Melucci and G. Sotgiu, Adv. Mater., 2005, 17, 1581.

13 A. Mishra, C.-Q. Ma and P. Bäuerle, Chem. Rev., 2009, 109, 1141.

14 F. Zhang, D. Wu, Y. Xua and X. Feng, J. Mater. Chem., 2011, 21, 17590.

15 N. Noma, T. Tsuzuki and Y. Shirota, Adv. Mater., 1995, 7, 647. 16 C. Videlot, A. El Kassmi and D. Fichou, Sol. Energy Mater. Sol. Cells, 2000, 63, 69.

17 R. de Bettignies, Y. Nicolas, P. Blanchard, E. Levillain, J.-M. Nunzi and J. Roncali, Adv. Mater., 2003, 15, 1939.

18 J. Sakai, T. Taima and K. Saito, Org. Electron., 2008, 9, 582. 19 (a) K. Schulze, C. Uhrich, R. Schüppel, K. Leo, M. Pfeiffer, E. Brier, E. Reinold and P. Bäuerle, Adv. Mater., 2006, 18, 2872; (b) R. Fitzner, E. Reinold, A. Mishra, E. MenaOsteritz, H. Ziehkle, C. Korner, K. Leo, M. Riede, M. Weil, O. Tsaryova, A. Weiss, C. Ulrich, M. Pfeiffer and P. Bäuerle, Adv. Funct. Mater., 2011, 21, 897; (c) R. Fitzner, C. Elschner, C. Uhrich, C. Körner, M. Riede, K. Leo, M. Pfeiffer, E. Reinold, E. Mena-Osteritz and P. Bäuerle, Adv. Mater., 2012, 24, 675 . 
20 F. Garnier, R. Hajlaoui, A. El Kassmi, G. Horowitz, L. Laigre, W. Porzio, M. Armanini and F. Provasoli, Chem. Mater., 1998, 10, 3334 .

21 (a) A. Yassin, T. Rousseau, P. Leriche, A. Cravino and J. Roncali, Sol. Energy Mater. Sol. Cells, 2011, 95, 462; (b) D. Demeter, T. Rousseau and J. Roncali, RSC Adv., 2013, 3, 704.

22 (a) V. Jeux, D. Demeter, P. Leriche and J. Roncali, RSC Adv., 2013, 3, 5811; (b) J. W. Choi, C. H. Kim, J. Pison, A. Oyedele, H. Derbal-Habak, D. Tondelier, A. Leliège, E. Kirchner, P. Blanchard, J. Roncali and B. Geffroy, RSC Adv., 2014, 4, 5236.

23 (a) H. Brisset, C. Thobie-Gautier, A. Gorgues, M. Jubault and J. Roncali, J. Chem. Soc., Chem. Commun., 1994, 1765; (b) J. Roncali and C. Thobie-Gautier, Adv. Mater., 1994, 6, 846; (c) P. Blanchard, H. Brisset, A. Riou and J. Roncali, J. Org. Chem., 1997, 62, 2401; (d) J. M. Raimundo, P. Blanchard, N. Gallego-Planas, N. Mercier, I. Ledoux-Rak, R. Hierle and J. Roncali, J. Org. Chem., 2002, 67, 205; (e) P. Blanchard, P. Verlhac, L. Michaux, P. Frère and J. Roncali, Chem.-Eur. J., 2006, 12, 1244.

24 (a) A. Leliège, C.-H. Le Régent, M. Allain, P. Blanchard and J. Roncali, Chem. Commun., 2012, 48, 8907; (b) A. Leliège, J. Grolleau, M. Allain, P. Blanchard, D. Demeter, T. Rousseau and J. Roncali, Chem.-Eur. J., 2013, 19, 9948; (c) D. Demeter, V. Jeux, P. Leriche, P. Blanchard, Y. Olivier, J. Cornil, R. Po and J. Roncali, Adv. Funct. Mater., 2013, 23, 4854.

25 Y. Ie, K. Nishida, M. Karakawa, H. Tada, A. Asano, A. Saeki, S. Seki and Y. Aso, Chem.-Eur. J., 2011, 17, 4750.

26 M. Löbert, A. Mishra, C. Uhrich, M. Pfeiffer and P. Bäuerle, J. Mater. Chem. C, 2014, 2, 4879.

27 A. Ojala, H. Bürckstümmer, J. Hwang, K. Graf, B. von Vacano, K. Meerholz, P. Erk and F. Würthner, J. Mater. Chem., 2012, 22, 4473.
28 S. Van Mierloo, P. J. Adriaensens, W. Maes, L. Lutsen, T. J. Cleij, E. Botek, B. Champagne and D. J. Vanderzande, J. Org. Chem., 2010, 75, 7202.

29 F. Effenberger, F. Würthner and F. Steybe, J. Org. Chem., 1995, 60, 2082.

30 M. J. Frisch, G. W. Trucks, H. B. Schlegel, G. E. Scuseria, M. A. Robb, J. R. Cheeseman, G. Scalmani, V. Barone, B. Mennucci, G. A. Petersson, H. Nakatsuji, M. Caricato, X. Li, H. P. Hratchian, A. F. Izmaylov, J. Bloino, G. Zheng, J. L. Sonnenberg, M. Hada, M. Ehara, K. Toyota, R. Fukuda, J. Hasegawa, M. Ishida, T. Nakajima, Y. Honda, O. Kitao, H. Nakai, T. Vreven Jr J. A. Montgomery, J. E. Peralta, F. Ogliaro, V. Bearpark, J. J. Heyd, E. Brothers, K. N. Kudin, V. N. Staroverov, R. Kobayashi, J. Normand, K. Raghavachari, A. Rendell, J. C. Burant, S. S. Iyengar, J. Tomasi, M. Cossi, N. Rega, J. M. Millam, M. Klene, J. E. Knox, J. B. Cross, V. Bakken, C. Adamo, J. Jaramillo, R. Gomperts, R. E. Stratmann, O. Yazyev, A. J. Austin, R. Cammi, C. Pomelli, J. W. Ochterski, R. L. Martin, K. Morokuma, V. G. Zakrzewski, G. A. Voth, P. Salvador, J. J. Dannenberg, S. Dapprich, A. D. Daniels, O. Farkas, J. B. Foresman, J. V. Ortiz, J. Cioslowski and D. J. Fox, Gaussian 09, Revision A.02, Gaussian, Inc., Wallingford CT, 2009.

31 A. D. Becke, J. Chem. Phys., 1993, 98, 5648.

32 S. M. Menke and R. J. Holmes, Energy Environ. Sci., 2014, 7, 499.

33 A. Guerrero, S. Loser, G. Garcia-Belmonte, C. J. Bruns, J. Smith, H. Miyauchi, S. I. Stupp, J. Bisquert and T. J. Marks, Phys. Chem. Chem. Phys., 2013, 15, 16456.

34 C. J. Brabec, A. Cravino, D. Meissner, N. S. Sariciftci, T. Fromhertz, M. T. Rispens, L. Sanchess and J. C. Hummelen, Adv. Funct. Mater., 2001, 11, 374.

35 C. Koerner, C. Elschner, N. C. Miller, R. Fitzner, F. Selzer, E. Reinold, P. Bäuerle, M. F. Toney, M. D. McGehee, K. Leo and M. Riede, Org. Electron., 2012, 13, 623. 